\title{
Earthquake Disaster Mitigation in Padang, Indonesia
}

\author{
Roni Ekha Putera ${ }^{1}$, Tengku Rika Valentina ${ }^{2}$, dan Irawati ${ }^{3}$ \\ roniekhaputera@soc.unand.ac.id ${ }^{1}$,tengkurika@soc.unand.ac.id ${ }^{2}$,irawati@soc.unand.ac.id ${ }^{3}$
}

Faculty of Social and Political Sciences, Universitas Andalas, Padang, Jl. Universitas Andalas, Limau

Manis, Pauh, Kota Padang, Sumatera Barat 25163, Indonesia

\begin{abstract}
The experience of a large earthquake has occurred in the past few years. Along the subdiction of the west coast of Sumatra, the 2004 Aceh Earthquake and tsunami, the Bengkulu Earthquake in 2007, the Padang Earthquake in 2009 and the Mentawai Earthquake and tsunami in 2010. Based on the research results of Nanyang Technology University and the Indonesian Institute of Sciences in Padang, the Mentawai Megatrusht subduction predicted to be 8.9SR. Such conditions, the City of Padang Government needs to prepare mitigation measures in efforts to reduce disaster risk. Qualitative interpretive research methods, data sources consist of primary data and secondary data. Primary data in the form of interviews and secondary data from the documentation review. The results showed that the Padang city government had prepared mitigation efforts carried out in the form of determining disaster-prone areas, the rules for building construction by earthquake standards, training, and disaster education, determining evacuation areas and evacuation routes. The Padang City Government has also installed earthquake evacuation signs and the making of SOPs in disaster-prone areas.
\end{abstract}

Keywords: Disaster Mitigation, Earthquakes, evacuation and the City of Padang..

\section{Introduction}

The issue of disaster management becomes an important matter to note considering that lately there are often natural disasters that hit the territory of Indonesia. It is related to the geographical condition of Indonesia which is on the active plate of the world and is in the Pacific fire ring "the pacific ring of fire "So that it often poses a threat to natural disasters, especially earthquakes and volcanic eruptions.

For this reason, in the Disaster Risk Reduction Framework according to the Research On The Social Science Committee (CDRSS), it covers at least 3 (three) important processes. First, Disaster Mitigation, which includes structural mitigation and non-structural mitigation. Second, Disaster Preparedness, which is to build people's readiness for disaster risk. Third, Emergency Response is responsiveness to disaster events [1].

Although natural disasters tend to be unavoidable, with high awareness and concern for disaster prevention measures, as well as mitigation efforts, the number of the victim due to disasters can be reduced at a much lower level. The occurrence of natural disasters that repeatedly occur in several regions in Indonesia such as the Aceh earthquake (2004), Yogyakarta (2006) Padang (2009) and Mentawai (2010) still do not bring disaster preparedness in the community. The phenomenon that occurs shows that the cultural conditions of the Indonesian people are still far from expectations. Communities and governments tend to be reactive and curative in the face of disasters. Disaster management is mostly done when a 
disaster has occurred and tends only to become a government affair, even though if you see from several studies showing that there is a participation between local actors, NGOs and the government in order to increase the capacity of the community to deal with disasters [2] [3]. [4]. [5]. [6]. Likewise, public awareness about disasters has only emerged when experiencing a disaster. In contrast to the experience of the Iranian State, for example, it has prepared and implemented a comprehensive plan for various aspects of disaster management policy [7] as well as Japan applies mitigation to individuals and communities in the face of disasters [8]. Meanwhile Rahmat (2006) [9]. Casualties and property in the event of natural disasters so far occur, more often caused by a lack of awareness and understanding of the government and the community regarding the potential for disaster vulnerability and mitigation efforts.

In Indonesia by of Law No. 242007 concerning disaster management, at the moment the focus of disaster management is more directed at community preparedness in the face of danger with the meaning of disaster management not only in the emergency response but also in predisaster actions (mitigation) by means of socializing and educating the public about earthquake, building rules, determining disaster-prone areas so that they can minimize and minimize the possibility of victims that will be caused by disasters [10].

Padang city as one of the areas with a high level of vulnerability of earthquakes [11], it is necessary to take steps to anticipate the worst possible impact of the earthquake disaster that will occur. For this reason, disaster mitigation measures become a matter that needs to be prepared by the Padang City government, moreover the current way of thinking in disaster management systems has undergone a change from the "relief" and 'response "paradigms to" contingency planning ", vulnerability reduction and disaster risk in the end towards more comprehensive disaster management [12].

Based on these explanations, it is interesting to study this paper in looking at the earthquake mitigation efforts carried out by the Padang City Government, considering the condition of Padang City which has a high level of vulnerability and vulnerability to the threat of earthquakes and tsunamis.

As the basis of the concept used is in explaining the earthquake mitigation efforts carried out by the Government of Padang City is what is proposed by Copalla [13], that disaster mitigation is a preventive effort carried out by the government and the community in an effort disaster risk reduction, mitigation is also defined as an action before a disaster occurs with the aim of eliminating and reducing the impact of disasters in society and the environment [14]. Mitigation is also often referred to as the basis of disaster management [15]. Copalla [11] divides mitigation into two types, namely structural mitigation and non-structural mitigation. Structural mitigation is defined as an effort to reduce disaster risk through development or changes in the physical environment through the application of designed solutions. These efforts include construction resilience, regulatory measures, and building codes, relocation, structural modification, construction of community housing, constraint construction or detection, physical modification, recovery systems, and infrastructure management for life safety. Nonstructural mitigation involves reducing the possibility or consequences of risk through modification of processes of human or natural behavior, without requiring the use of designed structures. In line with Copalla, Carter [16] states that disaster mitigation is divided into two types, namely nonstructural mitigation and structural mitigation. For non-structural mitigation, what is done is (1) Preparation of legislation, (2) Institutional formation, (3) Increasing public awareness, (4) Conducting training and education and (5) Providing incentives. While for structural mitigation carried out are (1) Making structural structures and (2) Engineering building structures.

While the main objective of disaster mitigation according to Copalla [13] is risk likelihood reduction, risk reduction, risk avoidance, risk acceptance, and risk transfer. This research places 
disaster mitigation as something urgent for the Padang City Government in order to reduce the risk of natural earthquake disasters. This study aims to analyze and explain the earthquake disaster mitigation efforts carried out by the City Government of Padang. So that we get a mapping of what the Padang City Government has taken actions or steps in reducing the risk of earthquake natural disasters.

\section{Methods}

This paper aims to examine how mitigation of natural disasters, especially earthquakes carried out in the city of Padang. Research is an interpretive quality that concentrates on the city of Padang. Data is collected in two categories: primary data and secondary data. Primary data is collected through in-depth and semi-structured interviews. For all semi-structured interviews the interview guide was given to look for answers to questions related to the earthquake disaster mitigation policy conducted by Kota Padang, while secondary data was collected from existing documents available at the Padang City Government or literature review. During data collection in Padang City in about four months, in-depth interviews were conducted with selected key informants who had knowledge of natural disaster mitigation in the city of Padang, both from the provincial government, local government, community leaders, local NGOs and international NGOs.

\section{Results and Discussion}

The public views disaster as something that comes from the outside and something that cannot be predicted and predicted, so it should be necessary to prepare themselves in order to anticipate the worst possible outcome of the disaster. Disaster is believed to be a form of warning, trial and rebuke to humans so that humans cannot avoid or prepare themselves to face it. Disasters that occur are godly and cannot be avoided, because if God has the will, anything can happen [18].

In connection with that, the city government and the community need to determine the steps in disaster risk reduction, with a level of concern and good understanding of course preparation in the face of the disaster that will occur will be better prepared. Victoria [19] argues that disaster mitigation and disaster risk reduction also offer a great opportunity to be able to integrate disaster management into the development planning process. Thus, the problem of disaster is an important thing in development. For example, in the city of Padang, prior to the 2004 Aceh earthquake, the city of Padang was an attractive coastal area to develop, so that in the strategic plan of Padang City, Padang was prioritized as a city called Water From City, which was included in the 2008 Padang RTRW -2028. However, after the Padang Earthquake in 2009, the development plan changed, where the changes were contained in the revision of the Padang City RTRW conducted in 2010. The changes that occurred in the RTRW began to consider disaster aspects in regional planning. The RTRW created with the aim is the City of Padang which is a metropolitan based disaster mitigation.

For this reason, in order to reduce the risk of disasters, there is a need for mitigation efforts in the response to earthquake natural disasters. This means that there is a need for efforts from the government and the community to make an introduction to disaster-prone areas and provide preparedness to the community. Debriefing can be done by increasing the capacity of the 
community in terms of disaster, so that the community understands and understands what must be done if the disaster comes. So that, with the increase in community capacity, it will be able to reduce the casualties that will result from the disaster.

The mitigation activities carried out in the form of structural and non-structural mitigation as stated by Copalla [13]. For the City of Padang disaster mitigation activities carried out can be explained as follows. Structural disaster mitigation activities carried out are (1) the revision of the disaster mitigation spatial-based spatial plan is contained in the Padang City regulation No. 4 of 2012, in the revised RTRW it was explained areas that were prone to disasters so that the area became a red zone for the community in carrying out physical development (2) Arrangement of Building and Housing development as stipulated in the city regulation No. Padang. 7 In 2015, in the regulation it was explained that the government set standards for the public, the private sector or the government in carrying out physical development, so that the building with resilience and strength against the threat of natural disasters such as earthquakes (3) infrastructure development by building disaster evacuation routes earthquakes that are currently available even though they have not been fully completed, the construction of this pathway is done to provide flexibility to the community in carrying out independent evacuation when an earthquake occurs, besides that the presence of this evacuation route provides guidance to the community for evacuation sites during natural disasters occur 4) Making maps and earthquake evacuation instructions with the intention of the community to know the direction and road for evacuation if a disaster comes. While the non-structural disaster mitigation activities carried out by the City Government of Padang are (1) socialization and simulation of disaster evacuation, this activity is carried out in every village and school in the city of Padang. This activity received a good response from the community, it was proven several times that the community actively participated in disaster planning, especially earthquakes. Besides, the Padang City Government in this case BPBD launched a disaster preparedness school program and disaster preparedness community. In addition to socialization through mosques, taklim assemblies, as well as door to door socialization, this activity means that the government has socialized directly to families and urban communities (2) community empowerment through Disaster Preparedness Groups (KSB) in each village. KSB is the spearhead in disaster mitigation, because with the active involvement of the KSB, the community should have the capacity that can be relied upon in responding to existing disasters.

\section{Conlusions}

Disaster mitigation activities carried out in the city of Padang have had a significant impact on the readiness of local governments and communities in efforts to reduce disaster risk. The various activities carried out in the mitigation of structural and non-structural disaster mitigation efforts carried out received support from the government, the private sector and the community.

In addition, the willingness to adopt disaster mitigation The efforts in the Padang City Spatial Plan show that a great effort that is feasible in this context is proof that local governments are more responsible for protecting the entire community. This change signifies a change in direction of regional government policies relating to conditions of pre-disaster conditions and the disaster mitigation efforts that they undertake.

\section{References}


[1] Committee on Disaster Research in The Social Sciences (CDRSS), 2006, Future Challengers and Opportunities Division on Earth and Life Studies, Facing Hazards and Disaster Understanding Human Dimensions, The National Academic Press

[2] Baytiyeh, Hoda and Mohamad Naja, Promoting earthquake disaster mitigation in Lebanon through civic engagement, Disaster Prevention and Management,Vol. 22 No. 4, 2013, pp. 340350, DOI 10.1108/DPM-05-2013-0080

[3] Djalante, Riyanti and Frank Thomalla, (2012),"Disaster risk reduction and climate change adaptation in Indonesia", International Journal of Disaster Resilience in the Built Environment, Vol. 3 Iss 2 pp. $166-180$ Permanent link to this document: http://dx.doi.org/10.1108/17595901211245260

[4] Kouzmin, Alexander, Alan M.G. Jarman and Uriel Rosenthal, Inter-organizational policy processes in disaster management, Disaster Prevention and Management Volume $4 \cdot$ Number 2 - $1995 \cdot$ pp. 20-37

[5] Mallick, Bishawjit and Joachim Vogt, Social supremacy and its role in local level disaster mitigation planning in Bangladesh, Disaster Prevention and Management Vol. 20 No. 5, 2011 pp. 543-556, DOI 10.1108/09653561111178970

[6] Mulyasari, Farah and Rajib Shaw . "Risk Communication through Community-based Society Organizations as Local Response to Disaster in Bandung, Indonesia" In Risks and Conflicts: Local Responses to Natural Disasters.; 231-250. http://dx.doi.org/10.1108/S20407262(2013)0000014016

[7] F. Nateghi-A., (2000),"Disaster mitigation strategies in Tehran, Iran", Disaster Prevention and Management: An International Journal, Vol. 9 Iss 3 pp. $205-212$. http://dx.doi.org/10.1108/09653560010335194

[8] Iwata,Kazuyuki, Yutaka Ito and Shunsuke Managi, Public and private mitigation for natural disasters in Japan International Journal of Disaster Risk Reduction 7 (2014) 39-50,

[9] Rachmat, Agus. (2006), Manajemen dan Mitigasi Becana, Makalah, Badan Pengendalian Lingkungan Hidup Daerah (BPLHD) Provinsi Jawa Barat

[10] Putera, Roni Ekha and Suherlan, When The Disaster Treatment In The Head Of Eyes: The Efforts Of Mitigation Policy And Reduction Of The Disaster Risk In Padang City, Journal of Arts, Science \& Commerce, Volume VI, Issue 4(1), October 2015; 42-48DOI URL : http://dx.doi.org/10.18843/rwjasc/v6i4(1)/05

[11] Putera, R., Nurasa, H., \& Sugandi, Y. (2018). Synergizing Stakeholders in Reducing Risk of Earthquake and Tsunami-Disaster in the Most Vulnerable Area. Bisnis \& Birokrasi Journal, 23(3). Retrieved August 11, 2018, from http://journal.ui.ac.id/index.php/jbb/article/view/9176/67545906

[12] Anwar, Herryal Z.; Harjono, Hery. (2013). Menggapai Cita-Cita Masyarakat Tangguh Bencana Alam di Indonesia. Bandung: Andira dan LIPI.

[13] Coppola, D. P. (2011). Introduction to International Disaster Management . Burlington, MA: Elsevier.

[14] King, D. (2007). Organisations in Disaster. Natural Hazard, 40, PP.657-665

[15] Federal Emergency Management Agency (FEMA) (2006). Tuscaloosa County Emergency Management Cycle diunduh tanggal 2 agustus 2017, dari www.tuscoema.org/cylce.html

[16] Charter, W. N. (2008). Disaster Management : A Disaster Manager's Handbook. Mandaluyong City, Manila: Asian Development Bank.

[17] Coppola, D. P. (2011). Introduction to International Disaster Management . Burlington, MA: Elsevier.

[18] Lindell MK, Prater CS and Perry RW (2006) Fundamentals of Emergency Management. Emmitsburg, MD: Federal Emergency Management Agency Emergency Management Institute. Di unduh tanggal 12 Agustus 2017 at www.training.fema.gov/EMIWeb/edu/fem.asp or archone.tamu.edu/hrrc/Publications/books/ index.html

[19] Victoria, Lorna P. 2007, Community Based Approached to Disaster Mitigation, di unduh tanggal 12 Agustus 2017, dari www.adpc.net/v2007/IKM/ONLINE\%20DOCUMENTS/downloads/.../CBDM.pdf 